\title{
Comparison of High Tunnel and Field Production of Specialty Cut Flowers in the Midwest
}

\author{
Michael A. Ortiz, Krystyna Hyrczyk, and Roberto G. Lopez ${ }^{1,2}$ \\ Department of Horticulture and Landscape Architecture, Purdue University, \\ 625 Agriculture Mall Drive, West Lafayette, IN 47907-2010
}

Additional index words. daily light integral, field production, stem caliper, stem length

\begin{abstract}
The U.S. specialty cut flower market has grown over the last several years because stems of many specialty cut flower species cannot be transported long distances and therefore need to be grown regionally. High tunnel production of cut flowers is an alternative to field and greenhouse production that has several benefits. Specialty cut flower species Antirrhinum majus L. 'Potomac Orange' and 'Rocket Red', Celosia argentea L. var. cristata Kuntze 'Chief Red', Dahlia $\times$ hybrida Cav. 'Karma Thalia Dark Fuchsia', Dianthus barbatus L. 'Amazon Neon Cherry', Eustoma russellianum Salisb. 'Mariachi Blue', Helianthus annuus L. 'Premier Lemon' and 'Sunrich Yellow', Matthiola incana (L.) W.T. Aiton 'Katz Lavender Blue', and Zinnia elegans Jacq. 'Benary Giant Scarlet' were grown in both field and high tunnel environments in the midwestern United States. High tunnel production resulted in a first week's harvest of 44.8 (46\%), 115, and 21.1 (110\%) more stems for Antirrhinum 'Rocket Red', Dianthus, and Zinnia, respectively. Compared with field production, high tunnel production yielded a greater number of stems $/ \mathrm{m}^{2}$ for Antirrhinum 'Potomac Orange', Celosia, Dianthus, and Zinnia and longer stems for Antirrhinum 'Potomac Orange' and 'Rocket', Eustoma, Matthiola, and Zinnia. For example, high tunnel production yielded 185 (39\%) and $192(59 \%)$ more stems $/ \mathrm{m}^{2}$ and $12.6(34 \%)$ and $8.9(32 \%) \mathrm{cm}$ longer stems for Mathiola and Zinnia, respectively. Other stem characteristics such as inflorescence length and flower width showed more variation among cultivars. Our results indicate that cut flower yield and/or quality of Antirrhinum 'Rocket Red', Dianthus, Matthiola, Zinnia, Dahlia, Eustoma, and Helianthus 'Sunrich Yellow' and 'Premier Lemon' significantly increases when produced in high tunnels located in the Midwest.
\end{abstract}

In 2011, the wholesale value of cut flowers grown in the top 15-producing states was \$359 million (USDA, 2012). Production has shifted to specialty cut flowers (i.e., species other than Rosa L., Dianthus caryophyllus L., Chrysanthemum $\times$ morifolium Ramat., and Alstromeria L.) that are not well adapted to long-distance transportation, and therefore proximity of production to market creates a competitive advantage (Koch, 1996; Wien, 2009; Yue and Hall, 2010). Specialty cut flower

\footnotetext{
Received for publication 9 Apr. 2012. Accepted for publication 9 July 2012

We gratefully acknowledge Diane Camberato, Veronica Hutchinson, Christopher Currey, Tristand Tucker, Nathan Linder, Kasey Clemons, Rachael Ehrlich, and Marc Duff for assistance; funding from growers providing support for Purdue University floriculture research; Purdue Mission Orientated Grant; and the Indiana Specialty Crop Block Grant 205009, Agreement \#A337-11-SCFM-004. We thank American Takii, Inc., PanAmerican Seed, Ernst Benary America Inc., Sakata Seed of America, Inc., C. Raker and Sons, and Vandenberg Bulb Co., Inc. for seeds and plugs.

The use of trade names in this publication does not imply endorsement by Purdue University of products named nor criticism of similar ones not mentioned.

${ }^{1}$ Associate Professor and Extension Specialist.

${ }^{2}$ To whom reprint requests should be addressed; e-mailrglopez@purdue.edu.
}

or double layer of greenhouse-grade 4- to 6mil plastic and typically has no electrical or heating systems (Carey et al., 2009; Montri and Biernbaum, 2009; Wells and Loy, 1993; Wien, 2009; Wien and Pritts, 2009). High tunnels have low construction and operating costs $\left(\$ 21\right.$ to 32 per $\mathrm{m}^{2}$ ), so growers can recover their investment within as little as 1 year (Blomgren et al., 2007; Carey et al., 2009).

Although crops in high tunnels receive a lower daily light integral (DLI) and altered air temperature compared with crops in the field, cut flowers usually develop significantly longer stems in high tunnels as a result of reduced air movement and irradiance (Wien, 2009; Wien and Pritts, 2009). In the northern United States, high tunnels offer protection from frost and low temperatures, extending the growing season by several weeks in both spring and fall (Wien, 2009). High tunnels also protect crops from rain and reduce disease incidence, so flower quality is maintained.

To our knowledge, no studies have been published on field and high tunnel production of the 10 selected specialty cut flower cultivars used in this study in the midwestern United States. These 10 cultivars were selected for this study based on low susceptibility to pest problems, ease of postharvest handling, and postproduction longevity, all of which characterize cut flower crops suitable for field production (Starman et al., 1995). The objectives of this study were to: 1) assess the weekly yield of 10 specialty cut flowers in both field and high tunnel production systems; 2) quantify differences between the field and high tunnel cut flowers; and 3) determine which of the selected crops are best suited for cut flower production in the midwestern United States.

\section{Materials and Methods}

$\$ 25,000$ to 30,000 per acre value (Byczynski, 2008).

Although there are many benefits to using highly mechanized greenhouses for cut flower production, there are high production and energy costs associated with their use (Wien, 2009). One way to overcome the high overhead costs of such production systems is growing specialty cut flowers in the field (Starman et al., 1995) or in non-mechanized, unheated high tunnels. The cost of growing specialty cut flowers in the field may be appealing, but the risk of extreme weather, seasonal production, and limited control options can be devastating for field-grown crops (Kelly, 1991). Studies have been conducted to assess specialty cut flower cultivar performance in field production systems in the southeastern United States (Starman et al., 1995). The productivity and profitability of field-grown specialty cut flower cultivars needs to be evaluated for other regions of the United States and in protected structures such as high tunnels to ensure successful growth of domestic specialty cut flowers.

A high tunnel is a single or multispan temporary structure made from pipe or other durable framework that is covered in a single
Plant material. On 11 Apr. 2011 Antirrhinum 'Rocket Red' (PanAmerican Seed, West Chicago, IL), Celosia 'Chief Red' (Sakata Seed America, Inc., Morgan Hill, CA), and Dianthus 'Amazon Neon Cherry' (PanAmerican Seed) seeds were sown into 105 -cell plug trays (28-mL individual cell volume; T.O. Plastics, Inc., Clearwater, MN) filled with a commercial soilless medium composed of $\approx 70 \%$ Canadian sphagnum peatmoss and $\approx 30 \%$ perlite (Super Fine Germinating Mix; Conrad Fafard, Anderson, SC). Seeds were covered with a thin layer of vermiculite (Sunshine; SunGro Horticulture, Bellevue, WA) to maintain moisture. On 18 Apr. 2011, Matthiola 'Katz Lavender Blue' (PanAmerican Seed) and Zinnia 'Benary Giant Scarlet' (Ernst Benary of America Inc., DeKalb, IL) seeds were sown as previously indicated, except Matthiola seeds were not covered with vermiculite. Dahlia 'Karma Thalia Dark Fuchsia' plugs (Vandenberg Bulb Co., Howell, MI) were received on 14 Apr. 2011 and transplanted into $12.7-\mathrm{cm}$ pots (1-L volume; Landmark Plastic, Akron, $\mathrm{OH}$ ) using the same soilless medium as previously described. 
Eustoma 'Mariachi Blue' plugs (C. Raker and Sons, Litchfield, MI) were received on 20 May 2011, transplanted into 105-cell plug trays, and placed under a natural photoperiod.

Air temperature during seed germination was maintained at $23.6 \pm 0.9{ }^{\circ} \mathrm{C}$ and the DLI was $14.7 \pm 2.3 \mathrm{~mol} \cdot \mathrm{m}^{-2} \cdot \mathrm{d}^{-1}$ during the $36 \mathrm{~d}$. Plant material was maintained in a glassglazed greenhouse with an exhaust fan and evaporative-pad cooling, radiant hot water, and retractable shade curtains controlled by an environmental control system (Maximizer Precision 10; Priva Computers Inc., Vineland Station, Ontario, Canada) at Purdue University, West Lafayette, IN (lat. $40^{\circ} \mathrm{N}$ ). An automatic woven shade curtain was retracted when the outdoor light intensity reached $1000 \mu \mathrm{mol} \cdot \mathrm{m}^{-2} \cdot \mathrm{s}^{-1}$ (OLS 50; Ludvig Svensson Inc., Charlotte, NC).

Plant material was moved to the field and high tunnel environments 1 week after the average last frost date for Tippecanoe, IN. On 16 and 17 May 2011, seeds of Helianthus 'Sunrich Yellow' (America Takii Inc., Salinas, CA) were directly sown and Celosia, Antirrhinum 'Rocket Red', Dianthus, Matthiola, Zinnia, and Dahlia were transplanted into raised beds in both a field and high tunnel environment. Eustoma were transplanted into the raised beds on 27 May 2011. On 13 July 2011, Antirrhinum 'Potomac Orange' (PanAmerican Seed) seeds were sown in the greenhouse as previously indicated. On 16 and 17 Aug. 2011, Helianthus 'Premier Lemon' (American Takii Inc.) seeds were directly sown and Antirhinnum 'Potomac Orange' (PanAmerican Seed) plugs were transplanted into the raised beds.

Plant culture. In the greenhouse, seedlings were irrigated as necessary with clear acidified water. Two weeks after germination, they were irrigated with acidified water supplemented with water soluble fertilizer to provide (in $\mathrm{mg} \cdot \mathrm{L}^{-1}$ ): $150 \mathrm{~N}, 15 \mathrm{P}, 118 \mathrm{~K}, 0.75$ $\mathrm{Fe}, 0.19 \mathrm{Cu}$ and $\mathrm{B}, 0.38 \mathrm{Mn}$ and $\mathrm{Zn}, 0.075 \mathrm{Mo}$ (Peters Excel@ Cal-Mag 21N-2.2P-16.5K; Everris, Marysville, $\mathrm{OH})$. In the greenhouse, Eustoma plugs were irrigated as necessary with acidified water supplemented with watersoluble fertilizer to provide (in $\mathrm{mg} \cdot \mathrm{L}^{-1}$ ): 200 $\mathrm{N}, 26 \mathrm{P}, 163 \mathrm{~K}, 50 \mathrm{Ca}, 20 \mathrm{Mg}, 1.0 \mathrm{Fe}, 0.5 \mathrm{Mn}$ and $\mathrm{Zn}, 0.24 \mathrm{Cu}$ and $\mathrm{B}$, and $0.1 \mathrm{Mo}$. Nutrients were supplied from a combination of two fertilizers, $900 \mathrm{mg} \cdot \mathrm{L}^{-1}$ (Peters Excel@ Cal-Mag $21 \mathrm{~N}-2.2 \mathrm{P}-16.5 \mathrm{~K})$ and $300 \mathrm{mg} \cdot \mathrm{L}^{-1}$ formulation (Peters Excel@ 15N-2.2P-12.5K). Irrigation water was supplemented with $93 \%$ sulfuric acid (Brenntag, Reading, PA) at 0.08 $\mathrm{mL} \cdot \mathrm{L}^{-1}$ to reduce alkalinity to $100 \mathrm{mg} \cdot \mathrm{L}^{-1}$ and $\mathrm{pH}$ to a range of 5.8 to 6.2 .

Field and high tunnel environments were located at the Meigs Farm of the Throckmorton Purdue Agriculture Center in Tippecanoe, IN (lat. $40.29^{\circ} \mathrm{N}$, long $86.88^{\circ} \mathrm{W}$ ). The soil type was Drummer (silty clay loam) with a $\mathrm{pH}$ of 7.2. Plants in the field and high tunnel were simultaneously irrigated with clear water supplemented with water-soluble fertilizer to provide (in $\mathrm{mg} \cdot \mathrm{L}^{-1}$ ): $100 \mathrm{~N}, 10 \mathrm{P}, 79$ $\mathrm{K}, 0.5 \mathrm{Fe}, 0.12 \mathrm{Cu}$ and $\mathrm{B}, 0.25 \mathrm{Mn}$ and $\mathrm{Zn}, 0.05$ Mo (Peters Excel@ Cal-Mag 21N-2.2P-16.5K).
On days of measurable rainfall, the high tunnel received clear water comparable to the rainfall amount. If extra nutrition was needed for specific cultivars, $150 \mathrm{ppm} \mathrm{N}$ (Peters Excel(C Cal-Mag 21N-2.2P-16.5K) was provided to each plot of that cultivar using a watering can.

Plot design. An east-west-oriented high tunnel $(14.6 \times 7.9 \times 3.7 \mathrm{~m}$ high $)$ with a triplegalvanized structural steel frame (FarmTek, Dyersville, IA) and 6-mm SunMaster ${ }^{\circledR}$ polyethylene film containing copolymer resin with trilayer construction and ultraviolet additives (Lumite, Baldwin, GA) that allowed 92\% light transmission was used for this experiment. Ventilation was provided by manually operated end wall peak vents and roll-up side walls. Side walls were rolled down as needed during periods of high winds. During periods when air temperature was above $4{ }^{\circ} \mathrm{C}$ and winds were calm, the high tunnel doors and vents were left open.

Eight raised beds $(12.2 \times 1.2 \times 0.15 \mathrm{~m}$ high) were used in total, four in the high tunnel and four in the field. All eight beds were amended using compost soil (Soilmaker, West Lafayette, IN) with a soil $\mathrm{pH}$ of 6.6. Each crop was randomly planted in each of the eight beds. Drip tape (T-Tape \# TSX 515-12-220; John Deere, Moline, IL) was installed in each bed at $\approx 0.3$-m spacing.

Environmental data collection. Resistancebased temperature sensors (External Temperature Sensor; Spectrum Technologies, Inc., Plainfield, IL), enclosed thermocouples, and quantum sensors recorded soil and air temperature and light intensity, respectively, every $20 \mathrm{~s}$ and averages were calculated every $15 \mathrm{~min}$ by a data logger (WatchDog Model 2475-Plant Growth Station; Spectrum Technologies, Inc.). Average DLI and air temperature were calculated for both locations for two growing periods. The first and second growing periods were from transplant to harvest for both the spring and fall crops (Table 1).

Data collection and analysis. Time to harvest (TTH) was recorded as the number of days from transplant or seed sow in the raised beds until the first stem was harvested for each plot. All plants within each block were used in recording the number of marketable stems, the total number of stems harvested per week, and the duration of the harvest period. Ten stems were selected at random from each block to record flower diameter, stem length, flower number, and stem caliper. Stem marketability was determined by length (greater than $30 \mathrm{~cm}$ ) and flower quality (no visual defects). Stems shorter than $30 \mathrm{~cm}$ and stems with damaged or disfigured flowers were deemed unmarketable.

Table 1. Spring and fall growing period, mean daily light integral (DLI), and air temperature for Antirrhinum, Celosia, Dahlia, Dianthus, Eustoma, Helianthus, Matthiola, and Zinnia cut flowers grown in the field or high tunnel.

\begin{tabular}{|c|c|c|c|c|}
\hline \multirow[b]{2}{*}{ Production period ${ }^{\mathrm{z}}$} & \multicolumn{2}{|c|}{ DLI $\left(\mathrm{mol} \cdot \mathrm{m}^{-2} \cdot \mathrm{d}^{-1}\right)$} & \multicolumn{2}{|c|}{ Temperature $\left({ }^{\circ} \mathrm{C}\right)$} \\
\hline & Field & $\overline{\text { High tunnel }}$ & Field & $\overline{\text { High tunnel }}$ \\
\hline 16 May to 14 Aug. & $49.8 \pm 15.1$ & $38.1 \pm 12.9$ & $25.0 \pm 3.0$ & $24.2 \pm 3.8$ \\
\hline 16 Aug. to 13 Nov. & $29.9 \pm 13.8$ & $21.8 \pm 10.1$ & $14.9 \pm 6.0$ & $15.2 \pm 5.7$ \\
\hline
\end{tabular}

${ }^{\mathrm{z}}$ Measured from transplant until end of last harvest.
The experiment was laid out in a randomized complete block design. Each block contained $\approx 40$ to 50 plants or five dahlia plants in a $1-\mathrm{m}^{2}$ area. For each crop, four blocks were grown in the high tunnel and four blocks were grown in the field. Data were analyzed using SAS (SAS Institute, Cary, NC) mixed model procedure (PROC MIXED), and pairwise comparisons between treatments were performed using Tukey's honest significant difference test.

\section{Results}

Antirrhinum 'Rocket Red'. In Week 1, $\approx 45$ more stems were harvested from the high tunnel than from the field (Table 2). The number of stems harvested from both the field and high tunnel decreased as time from first harvest increased. Field and high tunnel production yielded 158 and 183 stems, respectively, per square meter (Table 3 ). Stems grown in the field averaged $39.0 \mathrm{~cm}$ in length with 12.7-mm long inflorescences, whereas stems grown in the high tunnel averaged $51.8 \mathrm{~cm}$ in length with $16.3-\mathrm{mm}$ long inflorescences. Compared with field production, high tunnel production yielded $16 \%$ more stems $/ \mathrm{m}^{2}$, and stems were 33\% longer and had 29\% longer inflorescences. No significant differences were observed for stem caliper, flower width, or TTH between stems harvested in the field and high tunnel.

Antirrhinum 'Potomac Orange'. Data on number of stems harvested were pooled between the high tunnel and field because there was no significant difference between the interaction of environment and harvest week (Table 2). Number of stems harvested for the pooled data decreased as time from first harvest increased. Stems harvested from the high tunnel were on average $10.4 \mathrm{~cm}$ longer, but their caliper was $0.51 \mathrm{~mm}$ smaller than in the field (Table 3). No significant differences were observed for stems $/ \mathrm{m}^{2}$, inflorescence length, flower width, or TTH between the field and high tunnel.

Celosia. In Week 3, $\approx 24$ more stems were harvested from the high tunnel than the field (Table 2). No interaction occurred between number of stems harvested and time from first harvest for both the field and high tunnel. High tunnel production yielded 14 more stems $/ \mathrm{m}^{2}$ and TTH was reduced by $13 \mathrm{~d}$ compared with field production (Table 3 ). However, stems harvested from the high tunnel had $1.5 \mathrm{~mm}$ smaller flowers (width) than those harvested from the field. No significant differences were observed for stem caliper and inflorescence length between the field and high tunnel. 
Table 2. Number of Antirrhinum, Celosia, Dianthus, Eustoma, Helianthus, Matthiola, and Zinnia cut flower stems harvested each week from the field or high tunnel.

\begin{tabular}{|c|c|c|c|}
\hline Week & Field & & High tunnel \\
\hline \multicolumn{4}{|c|}{ Antirrhinum 'Rocket Red' } \\
\hline 1 & $98.0 \mathrm{a}^{\mathrm{z}} \mathrm{A}^{\mathrm{y}}$ & & $142.8 \mathrm{aB}$ \\
\hline 2 & $36.8 \mathrm{bA}$ & & $31.8 \mathrm{bA}$ \\
\hline 3 & $20.3 \mathrm{bA}$ & & $9.3 \mathrm{bB}$ \\
\hline Environment (E) & & NS & \\
\hline Week (W) & & $* * *$ & \\
\hline $\mathrm{E} \times \mathrm{W}$ & & * & \\
\hline \multicolumn{4}{|c|}{ Antirrhinum 'Potomac Orange' } \\
\hline 1 & & $12.3 \mathrm{a}^{\mathrm{x}}$ & \\
\hline 2 & & $0.0 \mathrm{c}$ & \\
\hline 3 & & $3.7 \mathrm{bc}$ & \\
\hline 4 & & $6.2 \mathrm{~b}$ & \\
\hline 5 & & $1.8 \mathrm{c}$ & \\
\hline Environment & & NS & \\
\hline Week & & $* * *$ & \\
\hline $\mathrm{E} \times \mathrm{W}$ & & NS & \\
\hline \multicolumn{4}{|c|}{ Celosia 'Chief Red' } \\
\hline 1 & $10.0 \mathrm{aA}$ & & $10.0 \mathrm{aA}$ \\
\hline 2 & $34.5 \mathrm{bA}$ & & $25.0 \mathrm{aA}$ \\
\hline 3 & $0.0 \mathrm{cA}$ & & $23.5 \mathrm{aB}$ \\
\hline Environment & & NS & \\
\hline Week & & $* * *$ & \\
\hline $\mathrm{E} \times \mathrm{W}$ & & *** & \\
\hline
\end{tabular}

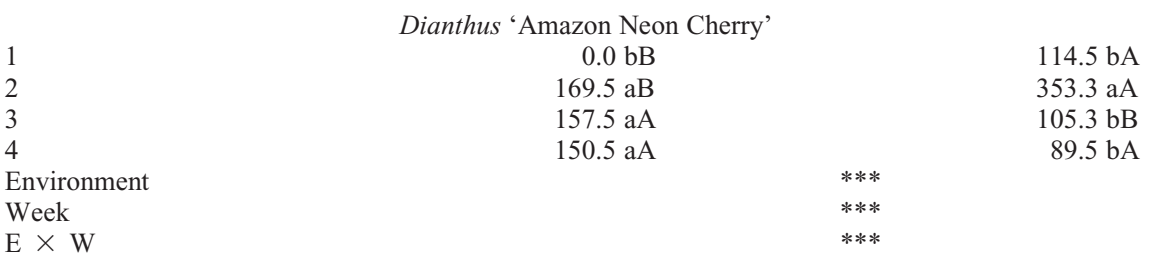

Eustoma 'Mariachi Blue'

2

Environment

Week

$\mathrm{E} \times \mathrm{W}$

1

2

Environment

Week

$\mathrm{E} \times \mathrm{W}$

1
2
3
Environment
Week
$\mathrm{E} \times \mathrm{W}$

Matthiola 'Katz Lavender Blue'

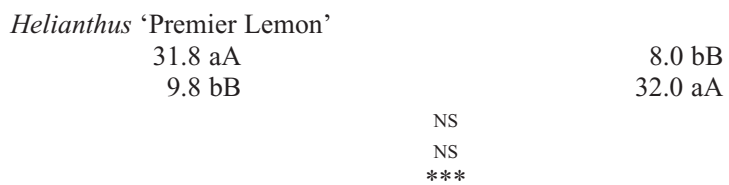

\section{$25.9 \mathrm{~b}^{\mathrm{x}}$}

$63.6 \mathrm{a}$

$37.1 \mathrm{~b}$

NS

$* * *$

NS

Zinnia 'Benary Giant Scarlet'
$19.3 \mathrm{bB}$
$24.5 \mathrm{bA}$
$16.5 \mathrm{bB}$
$40.3 \mathrm{bB}$
$120.8 \mathrm{aA}$
$103.3 \mathrm{aA}$

Dahlia. High tunnel TTH occurred, on average, $4 \mathrm{~d}$ earlier than in the field (Table 3 ). No significant differences were observed for stems $/ \mathrm{m}^{2}$, stem length, stem caliper, and flower width between the field and high tunnel.

Dianthus. In Weeks 1 and $2, \approx 115$ and 184 more stems were harvested from the high tunnel than the field, respectively (Table 2 ). In Week $3, \approx 52$ more stems were harvested from the field than the high tunnel. No significant interaction occurred between number of stems harvested and time from first harvest for both the field and high tunnel. High tunnel production yielded on average 185 more stems $/ \mathrm{m}^{2}$ and TTH was reduced by $10 \mathrm{~d}$ over field production (Table 3 ). Stems grown in the field averaged $6.8-\mathrm{mm}$ long inflorescences and $2.0-\mathrm{mm}$ wide flowers, whereas those grown in the high tunnel averaged 6.4-mm long inflorescences and 2.1-mm wide flowers. No significant difference was observed for stem length and caliper between the field and high tunnel.

Eustoma. Data on number of stems harvested per week were pooled between the high tunnel and field because there was no significant difference between the interaction of environment and harvest week (Table 2). Number of stems harvested for the pooled data increased as time from first harvest increased. Stems harvested from the high tunnel were, on average, $15 \mathrm{~cm}$ longer and flowers were $0.5 \mathrm{~mm}$ larger than stems harvested from the field (Table 3). No significant differences were observed for stems harvested per square meter, stem caliper, inflorescence length, or TTH between the field and high tunnel.

Helianthus 'Sunrich Yellow'. Stems harvested from the high tunnel had $3.9 \mathrm{~cm}$ longer stems and $1.4 \mathrm{~mm}$ larger flowers (width) than stems grown in the field (Table 3). No significant differences were observed for stem caliper or TTH between the field and high tunnel.

Helianthus 'Premier Lemon'. Number of stems harvested from the field decreased as time from first harvest increased. Number of stems harvested from the high tunnel increased as time from first harvest increased (Table 2). High tunnel TTH occurred, on average, $8 \mathrm{~d}$ earlier than in the field (Table 3 ). No significant differences were observed for stems harvested per square meter or stem caliper between the field and high tunnel.

Matthiola. Data on number of stems harvested were pooled between the high tunnel and field because no interaction occurred between environment and harvest week (Table 2). No interaction occurred between number of stems harvested and time from first harvest for the pooled data. Stems harvested from the high tunnel were $34 \%$ longer, had 32\% larger stem caliper, had inflorescences that were $21 \%$ longer, and had 24\% larger flowers (width) than stems grown in the field (Table 3). No significant differences were observed for stems harvested per square meter or TTH between the field and high tunnel.

Zinnia. In Weeks 1,3 , and $4, \approx 22,58$, and 55 more stems were harvested from the high 
Table 3. Number of marketable cut flower stems harvested per square meter, stem length, stem caliper, inflorescence length, flower width, and time to harvest (TTH) of Antirrhinum, Celosia, Dahlia, Dianthus, Eustoma, Helianthus, Matthiola, and Zinnia grown in the field or high tunnel. ${ }^{\mathrm{z}}$

\begin{tabular}{|c|c|c|c|c|c|c|}
\hline Environment & $\begin{array}{l}\text { Stems } / \mathrm{m}^{2} \\
\text { (no.) }\end{array}$ & $\begin{array}{l}\text { Stem length } \\
(\mathrm{cm})\end{array}$ & $\begin{array}{l}\text { Stem caliper } \\
(\mathrm{mm})\end{array}$ & $\begin{array}{l}\text { Inflorescence } \\
\text { length }(\mathrm{mm})\end{array}$ & $\begin{array}{c}\text { Flower } \\
\text { width }(\mathrm{mm})\end{array}$ & $\begin{array}{c}\mathrm{TTH} \\
\text { (days) }\end{array}$ \\
\hline & \multicolumn{6}{|c|}{ Antirrhinum 'Rocket Red' } \\
\hline Field & $157.5 \mathrm{~b}$ & $39.0 \mathrm{~b}$ & $6.1 \mathrm{a}$ & $12.7 \mathrm{a}$ & $3.5 \mathrm{a}$ & $37.0 \mathrm{a}$ \\
\hline High tunnel & $183.0 \mathrm{a}$ & $51.8 \mathrm{a}$ & $6.0 \mathrm{a}$ & $16.3 \mathrm{~b}$ & $3.4 \mathrm{a}$ & $37.3 \mathrm{a}$ \\
\hline \multirow[t]{2}{*}{ Significance } & $* * *$ & $* * *$ & NS & $* * *$ & NS & NS \\
\hline & \multicolumn{6}{|c|}{ Antirrhinum 'Potomac Orange' } \\
\hline Field & $18.8 \mathrm{a}$ & $71.8 \mathrm{~b}$ & $9.7 \mathrm{a}$ & $17.8 \mathrm{a}$ & $6.0 \mathrm{a}$ & $73.0 \mathrm{a}$ \\
\hline High tunnel & $20.0 \mathrm{a}$ & $82.2 \mathrm{a}$ & $9.2 \mathrm{~b}$ & $17.8 \mathrm{a}$ & $6.4 \mathrm{a}$ & $69.9 \mathrm{a}$ \\
\hline \multirow[t]{2}{*}{ Significance } & NS & $* * *$ & $*$ & NS & NS & NS \\
\hline & \multicolumn{6}{|c|}{ Celosia 'Chief Red' } \\
\hline Field & $44.5 \mathrm{a}$ & $-\mathrm{y}$ & $18.1 \mathrm{a}$ & $6.5 \mathrm{a}$ & $8.9 \mathrm{a}$ & $60.5 \mathrm{a}$ \\
\hline High tunnel & $58.5 \mathrm{~b}$ & - & $19.8 \mathrm{a}$ & $6.4 \mathrm{a}$ & $7.4 \mathrm{~b}$ & $47.5 \mathrm{~b}$ \\
\hline \multirow[t]{2}{*}{ Significance } & $* * *$ & - & NS & NS & $* * *$ & $* * *$ \\
\hline & \multicolumn{6}{|c|}{ Dahlia 'Karma Thalia Dark Fuchsia' } \\
\hline Field & - & $33.0 \mathrm{a}$ & $5.8 \mathrm{a}$ & - & $8.2 \mathrm{a}$ & $62.0 \mathrm{a}$ \\
\hline High tunnel & - & $34.1 \mathrm{a}$ & $5.3 \mathrm{a}$ & - & $8.3 \mathrm{a}$ & $58.3 \mathrm{~b}$ \\
\hline \multirow[t]{2}{*}{ Significance } & - & NS & NS & - & NS & $*$ \\
\hline & \multicolumn{6}{|c|}{ Dianthus 'Amazon Neon Cherry' } \\
\hline Field & $477.5 \mathrm{~b}$ & $51.2 \mathrm{a}$ & $8.3 \mathrm{a}$ & $6.8 \mathrm{a}$ & $2.0 \mathrm{~b}$ & $67.7 \mathrm{~b}$ \\
\hline High tunnel & $662.5 \mathrm{a}$ & $50.6 \mathrm{a}$ & $7.7 \mathrm{a}$ & $6.4 \mathrm{~b}$ & $2.1 \mathrm{a}$ & $58.4 \mathrm{a}$ \\
\hline \multirow[t]{2}{*}{ Significance } & $* * *$ & NS & NS & $*$ & $*$ & $* * *$ \\
\hline & \multicolumn{6}{|c|}{ Eustoma 'Mariachi Blue' } \\
\hline Field & $89.3 \mathrm{a}$ & $52.0 \mathrm{~b}$ & $8.8 \mathrm{a}$ & $21.5 \mathrm{a}$ & $6.0 \mathrm{~b}$ & $72.5 \mathrm{a}$ \\
\hline High tunnel & $90.0 \mathrm{a}$ & $66.7 \mathrm{a}$ & $9.2 \mathrm{a}$ & $19.0 \mathrm{a}$ & $6.5 \mathrm{a}$ & $72.5 \mathrm{a}$ \\
\hline \multirow[t]{2}{*}{ Significance } & NS & $* * *$ & NS & $* * *$ & NS & NS \\
\hline & \multicolumn{6}{|c|}{ Helianthus 'Sunrich Yellow' } \\
\hline Field & - & $59.1 \mathrm{~b}$ & $19.5 \mathrm{a}$ & - & $17.2 \mathrm{~b}$ & $66 \mathrm{a}$ \\
\hline High tunnel & - & $63.0 \mathrm{a}$ & $20.3 \mathrm{a}$ & - & $18.6 \mathrm{a}$ & $66 \mathrm{a}$ \\
\hline \multirow[t]{2}{*}{ Significance } & - & $*$ & NS & - & $*$ & NS \\
\hline & \multicolumn{6}{|c|}{ Helianthus 'Premier Lemon' } \\
\hline Field & - & $60.0 \mathrm{a}$ & $10.7 \mathrm{a}$ & - & - & $61.5 \mathrm{a}$ \\
\hline High tunnel & - & $60.3 \mathrm{a}$ & $11.4 \mathrm{a}$ & - & - & $54.0 \mathrm{~b}$ \\
\hline \multirow[t]{2}{*}{ Significance } & - & NS & NS & - & - & $* * *$ \\
\hline & \multicolumn{6}{|c|}{ Matthiola 'Katz Lavender Blue' } \\
\hline Field & $121.5 \mathrm{a}$ & $37.1 \mathrm{~b}$ & $6.4 \mathrm{~b}$ & $11.2 \mathrm{~b}$ & $3.5 \mathrm{~b}$ & $36.9 \mathrm{a}$ \\
\hline High tunnel & $131.8 \mathrm{a}$ & $49.7 \mathrm{a}$ & $9.3 \mathrm{a}$ & $14.2 \mathrm{a}$ & $4.3 \mathrm{a}$ & $37.4 \mathrm{a}$ \\
\hline \multirow[t]{2}{*}{ Significance } & NS & $* * *$ & $* * *$ & $* * *$ & $* * *$ & NS \\
\hline & \multicolumn{6}{|c|}{ Zinnia 'Benary Giant Scarlet' } \\
\hline Field & $324.5 \mathrm{~b}$ & $27.9 \mathrm{~b}$ & $5.8 \mathrm{~b}$ & - & $6.7 \mathrm{~b}$ & $35.6 \mathrm{a}$ \\
\hline High tunnel & $516.8 \mathrm{a}$ & $36.8 \mathrm{a}$ & $6.6 \mathrm{a}$ & - & $7.5 \mathrm{a}$ & $37.7 \mathrm{a}$ \\
\hline Significance & $* * *$ & $* * *$ & $* *$ & - & $* * *$ & NS \\
\hline
\end{tabular}

zValues within columns with the same letter are not significantly different by Tukey's honest significant difference test at $P \leq 0.05$.

y Data not collected.

$* * *, * * *$ Significant at $P \leq 0.05,0.01$, or 0.001 .

NS $=$ nonsignificant.

tunnel than the field, respectively (Table 2). Number of stems harvested from both the field and high tunnel increased as time from first harvest increased. Compared with field production, high tunnel production yielded $59 \%$ more stems $/ \mathrm{m}^{2}$, and stems were $32 \%$ longer, had $13 \%$ larger stem caliper, and $12 \%$ larger flowers by width (Table 3 ). No significant differences were observed in TTH between stems harvested in the field and high tunnel.

\section{Discussion}

Cut flower stems harvested from the high tunnel were significantly longer than stems
Yellow', Matthiola, and Zinnia, whereas stems of Celosia had larger flower widths when grown in the field compared with the high tunnel.

Cut flower growers consider stems marketable when the minimum stem length is between 30 and $41 \mathrm{~cm}$ (Barr, 1992; Koch, 1996; Starman et al., 1995; Verlinden and McDonald, 2007). In this study, we used $30 \mathrm{~cm}$ as the minimum stem length for a stem to be considered marketable. Our results are in agreement with previous reports that indicate that cut flower stems harvested in a high tunnel are longer (Wien, 2009).

Long stems may be desirable for florists, but other characteristics about the stems affect their performance as cut flowers for farmers' markets and wedding bouquets. When selecting cultivars for specialty cut flower production, traits of importance other than stem length are stem strength, earliness to flower, pest and disease resistance, heat tolerance, and vase life (Kelly, 1991). Stem caliper is generally a good indicator of stem strength. A long stem with a small stem caliper has a greater incidence of bending or breaking than a shorter stem of the same caliper or a stem of the same length with a larger stem caliper. Matthiola and Zinnia stems had significantly larger stem calipers when grown in the high tunnel than the field along with longer stem length as mentioned previously. When the combination of longer stem length and larger stem caliper for these two cultivars are taken together, high tunnel production may confer an advantage over field production when high-quality stems are desired. However, Antirrhinum 'Potomac Orange' stems were longer when grown in the high tunnel than in the field, but their stem calipers were smaller. This combination of characteristics led to problems supporting the stems in the high tunnel. For this reason, this cultivar is not suitable for high tunnel production in the Midwest.

During the spring and summer production period, the average DLI was $49.8 \pm 15.1$ and $38.1 \pm 12.9 \mathrm{~mol} \cdot \mathrm{m}^{-2} \cdot \mathrm{d}^{-1}$ in the field and high tunnel, respectively. The high tunnel frame and polyethylene glazing film only reduced light transmission by $\approx 23 \%$. Although crops in high tunnels received a lower DLI and altered air temperature compared with crops in the field, cut flowers usually develop significantly longer stems in high tunnels as a result of reduced air movement and irradiance (Wien, 2009; Wien and Pritts, 2009). As a result of shading from the greenhouse structure, glazing, and hanging objects, combined with the seasonal angle of the sun and cloud cover, greenhouse DLI rarely exceeds 25 $\mathrm{mol} \cdot \mathrm{m}^{-2} \cdot \mathrm{d}^{-1}$, even when conditions are favorable for high DLI (Torres and Lopez, 2010). Cut flower stem length is a good indicator of DLI received by the plants. Previous studies have reported that shading plants grown in the field using a $55 \%$ shadecloth increases stem length but consequently reduces cut flower yield (Armitage, 1991). These results suggest that the generalization that indicates lower DLI results in reduced yield or quality 
is not reliable when DLI values are above $25 \mathrm{~mol} \cdot \mathrm{m}^{-2} \cdot \mathrm{d}^{-1}$.

Another consideration for specialty cut flower growers is the TTH. Reduced TTH was observed for Celosia, Dahlia, Dianthus, and Helianthus 'Premier Lemon' when grown in the high tunnel as compared with the field. Reduced TTH ultimately leads to reduced input and labor costs and earlier marketability, an important consideration when deciding if the cost of constructing a high tunnel will be a wise investment. The small reduction in TTH in the high tunnel may be the result of mild or an otherwise conducive microclimate.

The results obtained from this study suggest that high tunnel production offers several benefits over field production when growing high-quality specialty cut flowers. However, the benefits associated with high tunnel production are cultivar-specific, because overall stem quality is a culmination of several characteristics. For example, high tunnel production yielding longer stems than field production alone is not enough to say that high tunnels yield higher quality stems. Variations within and among cultivars for stem quality can be caused by several variables. Therefore, our results indicate that high tunnel production is suitable for Antirrhinum 'Rocket', Celosia 'Chief Red', Dianthus 'Amazon Neon Cherry', Matthiola 'Katz Lavender Blue', Dahlia 'Karma Thalia Dark Fuchsia', Eustoma 'Mariachi Blue', Helianthus 'Sunrich Yellow' and 'Premier Lemon', and Zinnia 'Benary Giant Scarlet' in the Midwest.
Biotic and abiotic forces can also dramatically affect stem quality. Future studies should quantify the differences in biotic and abiotic stresses between field and high tunnel production. Further research is also needed to extend this study to other cultivars of specialty cut flowers, and research in different regions of the United States should be executed to provide more representative data for growers in a variety of locales to analyze when considering investing in high tunnel construction for the purpose of specialty cut flower production.

\section{Literature Cited}

Armitage, A.M. 1991. Shade affects yield and stem length of field-grown cut-flower species. HortScience 26:1174-1176.

Barr, C. 1992. The kindest cuts of all: How to evaluate new crops. Greenhouse Manager 11:82-84.

Blomgren, T., T. Frisch, and S. Moore. 2007. High tunnels: Using low cost technology to increase yields, improve quality, and extend growing season. Colchester, VT. 20 Oct. 2011. <http://www. uvm.edu/sustainableagriculture/Documents/ HighTunnels_Introduction.pdf $>$.

Byczynski, L. 2008. The flower farmer. Chelsea Green Publishing, White River Junction, VT.

Carey, E.E., L. Jett, W.J. Lamont, Jr., T.T. Nennich, M.D. Orzolek, and K.A. Williams. 2009. Horticultural crop production in high tunnels in the United States: A snapshot. Hort Technology 19:37-43.

Kelly, J.W. 1991. Field production of cut flowers. HortScience 26:1136-1138.

Koch, C. 1996. Field grown cut flowers. Ministry of Agriculture, Fisheries and Food. Floriculture Factsheet File No. 400-07.
Montri, A. and J.A. Biernbaum. 2009. Management of the soil environment in high tunnels. HortTechnology 19:34-36.

Starman, T.W., T.A. Cerny, and A.J. Mackenzie. 1995. Productivity and profitability of some field-grown specialty cut flowers. HortScience 30:1217-1220.

Torres, A.P. and R.G. Lopez. 2010. Measuring daily light integral in a greenhouse. $29 \mathrm{Jan} .2012$. $<$ http://www.extension.purdue.edu/extmedia/ $\mathrm{HO} / \mathrm{HO}-238-\mathrm{W} . \mathrm{pdf}>$

USDA. 2006. National Agricultural Statistics Service. Floriculture crops 2005 summary. 29 Jan. 2012. <http://usda01.library.cornell.edu/usda/ nass/FlorCrop//2000s/2006/FlorCrop-04-262006.pdf>.

USDA. 2012. National Agricultural Statistics Service. Floriculture crops 2011 summary. 2 June 2012. <http://usda01.library.cornell.edu/usda/ nass/FlorCrop//2010s/2012/FlorCrop -05-312012.pdf>.

Verlinden, S. and L. McDonald. 2007. Productivity and quality of statice (Limonium sinuatum cv. Soiree Mix) and cockscomb (Celosia argentea $\mathrm{cv}$. Chief Mix) under organic and inorganic fertilization regiments. Sci. Hort. 114:199-206

Wells, O.S. and J.B. Loy. 1993. Row covers and high tunnels enhance crop production in the northeastern United States. HortTechnology 3:92-95.

Wien, H.C. 2009. Floral crop production in high tunnels. HortTechnology 19:56-60.

Wien, H.C. and M.P. Pritts. 2009. Use of high tunnels in the northern USA: Adaption to cold climates. Acta Hort. 807:55-59.

Yue, C. and C. Hall. 2010. Traditional or specialty cut flowers? Estimating U.S. consumers' choice of cut flowers at noncalendar occasions. HortScience 45:382-386. 